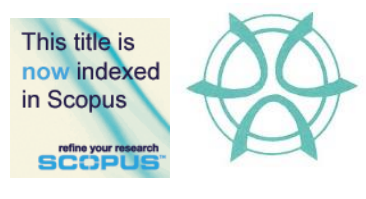

PLANNING MALAYSIA:

Journal of the Malaysian Institute of Planners

VOLUME 16 ISSUE 2 (2018), Page 186 - 196

\title{
THE RELEVANCY OF OUTDOOR CLASSROOM FOR PBL APPROACH IN SELECTED UNIVERSITY IN KUALA LUMPUR
}

\author{
Maheran Yaman ${ }^{1}$, Fadzidah Abdullah ${ }^{2}$, Nur Fadhilah Rozali ${ }^{3}$, \& Farha \\ Salim $^{4}$ \\ ${ }^{1,2,3,4}$ Kulliyyah of Architecture and Enviornmental Design, \\ INTERNATIONAL ISLAMIC UNIVERSITY MALAYSIA
}

\begin{abstract}
Outdoor classroom could be described as outdoor learning space that provides varying experiences and learning activities that could enhance students' learning performances, particularly in Problem Based Learning (PBL) approach. It also has become the main role in providing effective and dynamic learning environment for PBL practices. By investigating the relationship between the outdoor classroom and the students' PBL approach, one could reveal the interconnectedness between the outdoor classrooms in campus settings with the students' learning performances in PBL approach. Hence, the objective of this study is to analyze the relevance of outdoor classroom in adapting PBL approach in selected universities in Malaysia. A questionnaire survey, was conducted among landscape architecture and architecture students in UIAM, UPM and UiTM Puncak Alam. The results of this study confirm that outdoor classroom improves students learning performances, particularly in designing skills and work presentations. Furthermore, the results also indicate that outdoor classroom enhance students' ideas and inspiration in designing.
\end{abstract}

Keywords: outdoor classroom, PBL approach, campus informal learning, students' learning performances 
PLANNING MALAYSIA

Journal of the Malaysia Institute of Planners (2018)

\section{INTRODUCTION}

Problem Based Learning is a learning method that instructs students to develop their own investigation, research and construct their own solutions. It requires critical thinking with open-ended problems and facilitates by tutors and students in a small group. The PBL approach enables students to become actively participate in group work and develop viable learning solutions through selfdirected learning.

Group learning activities assist students in sharpening their communication skills, independent responsibility in sharing information and problem solving as well as learning to respect to other members. In other words, PBL is defined as '...specific attributes as being student-centered, taking place in small groups with the teacher acting as a facilitator, and being organized around problem' (Graaff \& Kolmos, 2003).

By definition, PBL is a pedagogical approach that uses 'real problem' as a trigger to problem-solving, in a way students understand the problems and encourage to find the new solutions and organize existing knowledge (Surif, Ibrahim \& Mokhtar, 2013). The principle idea of PBL is that the students is the problem solver and the facilitator monitors and guides students in the learning process. By PBL approach, students develop their problem-solving skills, personal skills, and social skills, as well as motivate themselves to learn new concepts and ideas through group discussion and formal conversation with the tutors.

Goodman (2010) summarizes the learning process in PBL by introducing the problems followed by the critical readings and identify the related issues (Figure 1). Next, a group discussion is established to do research and formulate ideas up to reaching proposal stages. Then, the outcomes are presented and discussed in the class, followed by the assessment to improve in group learning. Lastly, the discussion is made to proposed solutions and the final assessment is done through the implementation of successful problem-solving objectives. 


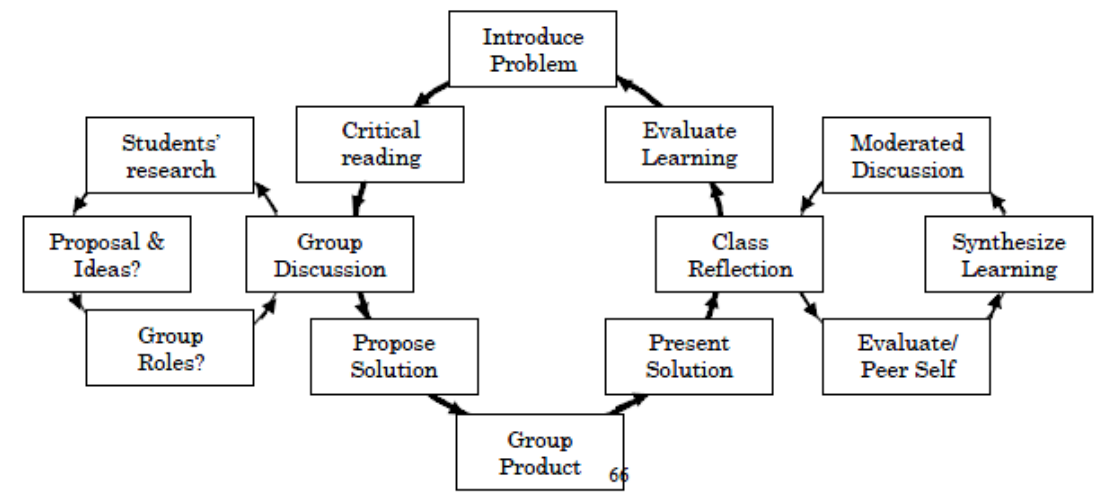

Figure 1: Learning process using problems

\section{PBL NEW PEDAGOGICAL APPROACH IN MALAYSIAN UNIVERSITIES}

The Ministry of Education has launched the MEB (Malaysian Education Blueprint) 2015-2025 for higher education to emphasize the balance between knowledge, skills, and morality. The student aspiration in MEB is built within the six cores of the attributes; ethics \& spiritually, leadership skills, national identity, language proficiency, thinking skills and knowledge (KPM, 2015).

Among the attributes, MOE highlights the leadership skills, thinking skills and knowledge as an essential component in creating the high employability skills that enable the graduates to compete with the global industry. Following the demand of the industry, the government assists the higher education institutions to develop the lifelong learning. This approach forms the graduates with potential professional skills and development of personal interests in the industry.

Within that, the Ministry constructed the education system that is less focused on traditional formal academic but prioritize technical and technologically related skills to cater students' needs and accomodate students with problem solving skills, creative and critical thinking skills and learning experience.

PBL is acknowledged as one of the pedagogical approaches that support the national aspiration aiming to deliver highly competent graduates (EPU, 2015). In recent years, the approach has become one of the effective approaches in teaching and learning settings that have gained considerable importance.

Historically, PBL was introduced in Malaysian educational landscape in the early 1970s, particularly in the health sciences (Borhan, 2012). Unfortunately, the approach has a slow growth with limited documentation of the outcomes. However, by the 1990s, medical and non-medical schools have started to use the 
PLANNING MALAYSIA

Journal of the Malaysia Institute of Planners (2018)

PBL approach in their learning practices and has been implementing the approach in variety of education fields, including engineering, information, and technology (ICT), nursing, teacher education, and architecture program (Letchumanan, 2008).

Generally, the implementation of PBL approach in Malaysian universities is more integrated into engineering and medical schools, following the other subject curricula. For example, Universiti Teknologi Malaysia (UTM) has developed the technology-based learning approach in its various engineering schools. The universities aiming to produce high-quality graduates with high attributes of professional knowledge and effective skills in communication, team working, problem-solving skills and lifelong learning (Khairiyah, Zaidatun, Jamalludin, \& Syed Ahmad, 2005). Borhan (2012) mentions that Universiti Malaya (UM) has implemented the PBL approach in the Department of Chemical Engineering to provide students with analytical skills, critical and creative thinking skills, technical skills, group work and time supervision.

Faculty of Education in UM has also incorporated PBL approach in teaching subjects to equip future teachers with high competency skills and effective teaching strategies. In addition, the implementation of the PBL approach in Universiti Sains Malaysia (USM) in medical schools also equips the students with the problem-based curriculum and community oriented skills through the combination of lectures, practical, fixed learning modules and clinical clerkship and problem-solving sessions.

\section{THE IMPROVEMENT OF STUDENTS' SKILL IN PBL}

The implementation of PBL in student learning has proven to give the positive impact on students' personal and social skills, through group participation and self-independent study. Masek, Yamin and Aris (2013) describe the active group participation enables students to communicate and reflect on the subject matter, while passive group participation discourages students from communicating and collaborating. Students that actively participate in group work tend to develop their communication skills, collaborative skills and also increase their level of confidence. Furthermore, students are motivated to enhance their contribution to group discussion through sharing ideas and information, deliver solutions and engage in discussions admittedly.

As PBL is an instructional learner-centered approach that empowers students to identify issues, conduct research and apply knowledge, students are responsible for conducting self-directed learning; providing the ideas and solutions towards the complex problem. Learner motivation increases when responsibility for the problem-solving process rests on the learners to seek information and share the relevant resources during the discussion (Savery, 2006; Letchumanan, 2008). Moreover, PBL session enhances students' abilities to learn through creative and critical thinking in analyzing and solving the real problem, 
Maheran Yaman, Fadzidah Abdullah, Nur Fadhilah Rozali, \& Farha Salim

The Relevancy of Outdoor Classroom for PBL Approach in Selected University in Kuala Lumpur

improving collaboration and interaction through sharing information and work productivity, as well as improving the concentration and self-motivation in independent learning.

\section{ADAPTING OUTDOOR CLASSROOM IN PBL CONTEXT}

In the outdoor classroom context, the learning spaces are functioning as part of integrated learning space between indoors and the outdoors. To promote an active learning environment, the flexible and multi-use of the outdoor classroom spaces are required. Students during PBL practices need bigger spaces that can support their learning activities, as well as increase their cognitive development through focus and concentration.

Moreover, students establish their relationship between the outdoor physical environment with their social behaviour (Shamsuddin, Bahauddin \& Aziz, 2012). The application of ergonomic consideration in terms of moveable furniture is essential in the outdoor classroom, as to accommodate students with diverse learning activities and to encourage comfortable group discussions and informal conversations (Oblinger, 2006).

The development of new teaching-learning methods have brought different perspectives in outdoor learning spaces in a campus environment (Abdullah, Beh, Tahir, Che Ani, \& Tawil, 2011). The learning spaces become the crucial role in providing the most effective and dynamic learning environment for PBL practices. Hence, the importance of physical environment towards pedagogical approaches is important to be designed and constructed with more student-centered learning approaches. Diverse outdoor classroom with technology supports and various facilities are another significant criteria of outdoor learning spaces that not only encourage students to learn outdoors but also promote the virtual environment with support by wireless connection and electrical capabilities. The outdoor classroom could be easily transformed from a casual area to the vigorous gathering and meeting place. Oblinger (2005) describes the importance of learning space as 'An active, collaborative teaching and learning philosophy is often manifested in a different design. The outdoor spaces can either inhibit or enable different styles of teaching as well as learning practices'.

In response to achieve the collaboration process and develop the critical and creative thinking skills in the outdoor classroom, the new learning spaces incorporate the technology and multi sensory experiences are desired. This type of outdoor classroom supports the changes of the learning activities and allow students to engage with the natural environment and create a sense of place. Moreover, an effective outdoor classroom that promotes interactions and movements supports students' active learning through group discussions and collaborative atmosphere. 
PLANNING MALAYSIA

Journal of the Malaysia Institute of Planners (2018)

As PBL approach practices students with self-directed learning, the essential aspects of the physical environment on campus outdoors must be effective in terms of varying design elements and places with pleasant environment (Ibrahim, Fadzil, \& Saruwono, 2013). The informal learning spaces should also accommodate various settings that range from group learning spaces to the individual spots for privacy. The range of learning spaces will enhance students' learning performances and stimulate student-centered learning in the outdoors. Flexible outdoor classroom spaces encourage multiple learning activities to support students' personal skills in the PBL practices.

\section{METHODS}

300 students from Department of Architecture and Landscape Architecture in three selected universities; UIAM, UPM and UiTM Puncak Alam were selected as target respondents for the questionnaire survey. The data were analyzed using Statistical Package for Social Science (SPSS). The open-ended questions were coded and categorized according to the significant findings of the students' perception and experience in PBL sessions.

\section{ANALYSIS AND FINDINGS}

Table 1 shows the significant findings of the effectiveness PBL approach in students' learning performances, particularly in the student's skills development. The opinions were generally to identify the student's perception on the PBL practices relevant to their interest and enhance their curiosity in real career world. 
Maheran Yaman, Fadzidah Abdullah, Nur Fadhilah Rozali, \& Farha Salim

The Relevancy of Outdoor Classroom for PBL Approach in Selected University in Kuala Lumpur

Table 1: Significance student skills performances in PBL approach

\begin{tabular}{|c|c|c|}
\hline \multirow{3}{*}{ Personal Skills Performances } & \multicolumn{2}{|c|}{ Opinion } \\
\hline & \multicolumn{2}{|c|}{$\begin{array}{l}\text { To allow students to provide feedback regarding the course relevant to } \\
\text { student interest and the curiosity about the real career world }\end{array}$} \\
\hline & $\begin{array}{l}\text { Course relevant to student } \\
\text { interest }\end{array}$ & $\begin{array}{l}\text { Arose curiosity on real career } \\
\text { world }\end{array}$ \\
\hline 1. Interpersonal skills & $\begin{array}{ll}- & \text { Face real challenges } \\
- & \text { Develop curiosity and focus }\end{array}$ & $\begin{array}{ll}\text { - } & \text { Gives awareness and } \\
\text { develop knowledge } \\
\text { Students are more } \\
\text { concerned with problem } \\
\text { solving } \\
\text { Environmental context } \\
\text { cultivates student's } \\
\text { curiosity } \\
\text { Optimistic } \\
\end{array}$ \\
\hline 2. Communication skills & $\begin{array}{l}\text { Able to communicate with } \\
\text { the client to solve the } \\
\text { issues }\end{array}$ & - \\
\hline 3. Collaborative skills & - & $\begin{array}{ll}- & \text { Improve interaction among } \\
\text { students and tutors } \\
\text { - Student's involvement with } \\
\text { local community }\end{array}$ \\
\hline 4. Technology and technical skills & - & - \\
\hline $\begin{array}{l}\text { 5. Critical and creative thinking } \\
\text { skills }\end{array}$ & $\begin{array}{l}\text { - Confident and creative } \\
\text { thinking } \\
\text { Desire to solve the issues } \\
\text { passionately }\end{array}$ & $\begin{array}{l}-\quad \text { Develop critical thinking } \\
\text { Tendency to solve the } \\
\text { issues }\end{array}$ \\
\hline 6. Self-learning skills & $\begin{array}{l}\text { - } \\
\text { new knowh learn and adapt } \\
\text { neal experience as } \\
\text { preparation in the field } \\
\text { work }\end{array}$ & $\begin{array}{ll}\text { - } & \text { Curiosity to manage self- } \\
\text { learning } \\
\text { Increasing students time to } \\
\text { develop self - centered } \\
\text { learning }\end{array}$ \\
\hline 7. Emotional intelligence skills & - & $\begin{array}{l}\text { Students able to examine } \\
\text { the issues and develop the } \\
\text { methods } \\
\text { More practical learning }\end{array}$ \\
\hline 8. Generic skills & $\begin{array}{l}\text { Understand the theory } \\
\text { through problem solving } \\
\text { Efficient learning activities } \\
\text { improve students' } \\
\text { experiences in real problem }\end{array}$ & $\begin{array}{ll}- & \text { Providing initial ideas of } \\
\text { problem solving } \\
\text { Students well prepared to } \\
\text { become professional } \\
\text { graduates }\end{array}$ \\
\hline
\end{tabular}

Based on the result, Students from both departments and respective universities agreed that the PBL practices in design-based learning were relevant to their interest. It shows that PBL practices improved the personal skills and promoted life-long learning. Students were able to learn and adapted to new knowledge and had the confidence to face the real challenges. Other than that, students also agreed that they improved their communication skills, especially with the practitioners and able to solve the critical issues during the work project. In addition, the result shows that students also agreed that PBL practices increased their curiosity about the real career world. Students were more concern on the real world situations and to develop the critical thinking in problem- 
PLANNING MALAYSIA

Journal of the Malaysia Institute of Planners (2018)

solving. The students developed the practicality in designing for community demands as well as designing outdoor spaces by adapting the environment and hardscape element for users' needs.

Other than that, students improved their interaction and collaborative teamwork among peers and tutors, and active engagement with real world assignments. PBL also fostered students with social learning, that is, allowing students to create interaction and contribution in the group discussion and also boosted the confidence level in presenting views and opinions in the discussion session.

Table 2 illustrates the findings of the outdoor classroom adaptability with the PBL approach. The analysis indicated that outdoor settings provide appropriate spaces that encourage students to develop their active learning and improve the social interaction among students and tutors.

The students agreed the outdoor classroom improved students' collaborative skills. The spaces created an interesting environment for group discussions with flexible furnitures. Other than that, nature ambiance engaged students with landscape elements and promoted relaxation when studying or socializing. The effective outdoor classroom also encouraged students to work collaboratively and be able to concentrate on completing the projects.

It was also clearly stated that the studio-project was more flexible in outdoor classrooms. The outdoors enabled students to learn and increase their design skills. The results stated that students tend to develop their design skills in interesting environment that allow the students to observe and developed various ideas.

Other than that, students were able to visualize the design work and be inspired by referring and adapting to surroundings that suit users' needs. Variety of spaces in the outdoors also enabled students to adapt to new learning experiences and develop critical and creative thinking on deciding the spaces that need to be designed. Lastly, applying design project in an outdoor classroom helped students to develop their restorative health and promote healing through engagement with nature and contemplation area. 
Maheran Yaman, Fadzidah Abdullah, Nur Fadhilah Rozali, \& Farha Salim

The Relevancy of Outdoor Classroom for PBL Approach in Selected University in Kuala Lumpur

Table 2: Effective outdoor classroom adaptability with the PBL approach

\begin{tabular}{|c|c|c|}
\hline \multirow{3}{*}{$\begin{array}{l}\text { Student's perception on } \\
\text { Outdoor Classroom }\end{array}$} & \multicolumn{2}{|c|}{ Opinion } \\
\hline & \multicolumn{2}{|c|}{$\begin{array}{l}\text { To allow students to provide feedback regarding the outdoor classroom does } \\
\text { promote collaborative and designing skills in PBL practices }\end{array}$} \\
\hline & Promote collaborative skills & Promote designing skills \\
\hline $\begin{array}{l}\text { 1. Outdoor Classroom provides } \\
\text { sufficient spaces for learning } \\
\text { activities }\end{array}$ & 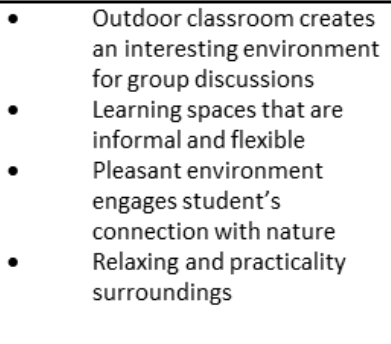 & $\begin{array}{l}\text { More relaxation in the } \\
\text { outdoor area } \\
\text { Visual analysis in outdoor } \\
\text { campus improves design } \\
\text { skills } \\
\text { Connection to nature } \\
\text { improve student design skills } \\
\text { The interesting outdoor } \\
\text { environment allows } \\
\text { students to observe varies } \\
\text { ideas }\end{array}$ \\
\hline $\begin{array}{l}\text { 2. Studio project is more flexible in } \\
\text { the outdoors }\end{array}$ & $\begin{array}{ll}- & \text { Experience in real situations } \\
\text { Outdoor spaces encourage } \\
\text { students to work together }\end{array}$ & $\begin{array}{l}\text { - } \quad \begin{array}{l}\text { The student gets inspired in } \\
\text { the outdoors } \\
\text { Students inject new } \\
\text { experience in the real world }\end{array} \\
\end{array}$ \\
\hline $\begin{array}{l}\text { 3. Students enable to learn tasks } \\
\text { quickly }\end{array}$ & $\begin{array}{ll}-\quad \text { Improve critical thinking } \\
\text { Students have actively } \\
\text { participated in a thorough } \\
\text { discussion with tutors } \\
\text { Students more focused } \\
\text { when in the outdoors }\end{array}$ & $\begin{array}{l}\text { - } \\
\text { Students develop their } \\
\text { learning skills by referring } \\
\text { and adapting the outdoor } \\
\text { environment that suits the } \\
\text { user's needs } \\
\text { Students develop their } \\
\text { practicality in designing } \\
\text { outdoor spaces } \\
\text { Gain knowledge of the real } \\
\text { process of learning }\end{array}$ \\
\hline $\begin{array}{l}\text { 4. Outdoor classroom improved PBL } \\
\text { practices in personal skills }\end{array}$ & $\begin{array}{l}\text { - } \\
\text { Boost confident in } \\
\text { communication } \\
\text { Enhance skills and achieve } \\
\text { different ideas } \\
\text { Tutors as facilitator and } \\
\text { guide students in problem- } \\
\text { solving } \\
\text { Students improve } \\
\text { communication skills with } \\
\text { peers and tutors }\end{array}$ & $\begin{array}{l}\text { Improve communication } \\
\text { skills among students and } \\
\text { tutors }\end{array}$ \\
\hline
\end{tabular}

\section{CONCLUSION}

Generally, the PBL approach supports students' various learning disciplines. The approach accommodates the students with self-directed learning through improving soft skills. An outdoor classroom is seen as a relevant learning space to cater the learning needs and support the consistency of student-centered learning. Surif et al. (2013) describe that the PBL approach requires students to be 'problem-solver' and actively participate in the discussion and teamwork, as the problems require high level of personal skills performances. The study has shown that the outdoor classroom affects students' physical and psychological development. Through providing various learning spaces and adequate outdoor facilities to support students' learning needs, the outdoors improve students' learning experiences. 
In order to improve the students' learning performances, the study suggests for the outdoor learning spaces to emphasize the areas suitable for tertiary level. This include providing the sufficient spaces for learning activities, flexible area for studio project and group assignment, spaces with suitable accommodation and excellent facilities including technology and technical appliances as well as the outdoor area that can improve the students' psychological behavior.

The outdoor classroom in campus is also designed to support the visual, nature and image enhancement for the institutions.

\section{ACKNOWLEDGEMENT}

This work was supported by International Islamic University Malaysia.

\section{REFERENCES}

Abdullah, N. A. G., Beh, S. C., Tahir, M. M., Che Ani, A. I., \& Tawil, N. M. (2011), Architecture design studio culture and learning spaces: A holistic approach to the design and planning of learning facilities. Procedia - Social and Behavioral Sciences, 15, 27-32.

Borhan, M. T., (2012). Problem based learning (PBL) in Malaysian higher education: A review of research on learners experience and issues of implementations. ASEAN Journal of Engineering Education, 1(11), 48-53.

Economic Planning Unit [EPU] (2015). Eleventh Malaysian Plan. Retrieved from http://epu.gov.my/en/rmk/eleventh-malaysia-plan-2016-2020

Graaff, E. D. E. \& Kolmos, A. (2003). Characteristics of problem-based learning. International Journal of Engineering Education, 19(5), 657-662.

Goodman, R. J. B. (2010). Problem-based learning: Merging of economics and mathematics. Journal of Economics and Finance. 34(4), 477-483.

Ibrahim, N., Fadzil, N. H., \& Saruwono, M. (2013). Learning outside classrooms on campus ground: Malaysia. Asian Journal of Environment-Behaviour Studies, 4(13), 97-110

Khairiyah, M. Y., Zaidatun, T., Jamalludin, H., \& Syed Ahmad, H. (2005). Promoting problem-based learning (PBL) in engineering courses at the Universiti Teknologi Malaysia. Global Journal of Engineering Education, 9(2), 175-184.

Letchumanan, M. (2008). Problem Based Learning in Mathematics. Research Bulletin of Institute for Mathematical Research, 21-25.

Masek, A., Yamin, S., \& Aris, R. (2013, July). Students participation and facilitation in PBL tutorial session. 4th International Research Symposium on Problem Based Learning (IRSPBL 2013). July 2-3, 2013, Putrajaya, Malaysia.

Ministry of Education Malaysia [KPM] (2015). Malaysia Education Blueprint 2015-2025 (Higher Education). 
Maheran Yaman, Fadzidah Abdullah, Nur Fadhilah Rozali, \& Farha Salim

The Relevancy of Outdoor Classroom for PBL Approach in Selected University in Kuala Lumpur

Oblinger, D. G. (2006). Learning spaces. British Journal of Educational Technology, 41.

Oblinger, D. (2005). Leading the transition from classrooms to learning spaces. EDUCAUSE Quarterly, 28(1), 14-18.

Savery, J. (2006). Overview of problem-based learning: Definitions and distinctions. Interdisciplinary Journal of Problem Based Learning, 1(1), 269-282.

Shamsuddin, S., Bahauddin, H., \& Aziz, N. A. (2012). The relationship between the outdoor physical environment and students' social behavior in urban secondary school. Procedia-Social and Behavioral Sciences, 50, 148-160.

Surif, J., Ibrahim, H., \& Mokhtar, M. (2013, July). Implementation of problem based learning in higher education institutions and its impact on students' learning. 4th International Research Symposium on Problem Based Learning (IRSPBL 2013). July 2-3, 2013, Putrajaya, Malaysia. 